\title{
CONSELHO DE REPRESENTANTES DOS CONSELHOS DE ESCOLA (CRECE): A EXPERIÊNCIA DE GESTÃO DEMOCRÁTICA DE UM BAIRRO EDUCADOR NA CAPITAL PAULISTA 1
}

\author{
COUNCIL OF REPRESENTATIVES OF SCHOOL COUNCILS (CRECE): THE DEMOCRATIC \\ MANAGEMENT EXPERIENCE OF AN EDUCATING NEIGHBOURHOOD IN SÃO PAULO
}

\author{
CONSEJO DE REPRESENTANTES DE LOS CONSEJOS ESCOLARES (CRECE): LA \\ EXPERIENCIA DE GESTIÓN DEMOCRÁTICA DE UN BAIRRO EDUCATIVO DE LA CAPITAL \\ PAULISTA
}

Cileda Santos Sant'Anna Perrella²

\begin{abstract}
RESUMO
A gestão democrática da escola pública, um princípio constitucional, está comprometida com a cidade educadora via instauração de espaços democráticos de participação. O Conselho de Representantes dos Conselhos de Escola (CRECE) é um desses espaços com potencial articulador de ações territorialmente, provocando o diálogo entre as escolas e delas com a estrutura do sistema, apresentando, debatendo, deliberando questões voltadas à garantia de direitos dos cidadãos. Este texto decorre de pesquisa acadêmica que teve como objeto de estudo o CRECE e trata da experiência do CRECE do bairro de São Mateus, localizado na zona leste da capital paulista. Tem por objetivo apresentar a articulação de ações democratizantes e educativas realizadas entre ações do governo local e o referido conselho regional (CRECE) alinhadas à proposta da cidade educadora. Para responder a questão, sobre como foi possível impulsionar ações articuladas entre governo e sociedade civil, a metodologia utilizada foi de abordagem qualitativa recorrendo a análise documental e entrevistas (CELLARD, 2008; BOURDIEU, 2001). Teoricamente, foram importantes as contribuições de Paulo Freire, Luciana Tatagiba, Vitor Paro, entre outros. A experiência revelou que, para a criação e fortalecimento de espaços democráticos de participação na cidade como o CRECE, faz-se necessário um passo-a-passo nas ações devendo estar presente a dialogicidade bem como a construção coletiva. Conclui que o CRECE apresenta potencial formador e articulador revelando nuances de um bairro constituindo-se com perfil educador.
\end{abstract}

PALAVRAS-CHAVE: Conselho. Gestão Democrática. Participação. Cidade Educadora. Relação governosociedade.

\footnotetext{
${ }_{1}^{1}$ Pesquisa de Pós-doutorado intitulada XXXX, realizada junto ao Departamento de Educação da Universidade $X X X$, no período XXXX (AUTORA, ANO)

2 Mestrado e doutorado em educação pela Faculdade de Educação da Universidade de São Paulo. Pós Doutorado pelo Departamento de Educação da Universidade Federal de São Carlos. Coordenadora Pedagógica da Rede Municipal de Ensino de São Paulo (aposentada). Tem experiência em assessorar Secretarias de Educação (Gestão escolar e formação de professores). Pesquisadora da Rede EScola Pública e Universidade (REPU). Projetos de Pesquisa em andamento: Estudos de Revisão em Educação: tipologias e tendências metodológicas; Política educacional na rede estadual paulista (1995 a 2018). Livros publicados: Formação e participação políticas de conselheiros e conselheiras de escola; A escola pública feita por várias mãos (org com Rubens Barbosa de Camargo) ambos Editora Appris. Interesse: gestão escolar democrática, organização do trabalho na escola, política e gestão educacional.
} 


\begin{abstract}
Democratic management of public schools, a brazilian constitutional principle, is committed to the educating city through the establishment of democratic spaces for participation. The Council of School Council Representatives (CRECE) is one of these spaces with the potential to articulate territorial actions, encouraging dialogue between schools and between them and the system's structure, presenting, debating and deliberating issues aimed at ensuring citizens' rights. This text stems from academic research that had as its object of study the CRECE and deals with the experience of the CRECE in the district of São Mateus, located in the eastern zone of São Paulo. It aims to present the articulation of democratizing and educational actions carried out between local government actions and the aforementioned regional council (CRECE) in accordance with the proposal of the educating city. To answer the question about how it was possible to promote articulated actions between government and civil society, the methodology used was a qualitative approach using document analysis and interviews (CELLARD, 2008; BOURDIEU, 2001). Theoretically, the contributions of Paulo Freire, Luciana Tatagiba, Vitor Paro, among others, were important. The experience revealed that, for the creation and strengthening of democratic spaces for participation in the city such as CRECE, a step-by-step approach is necessary, and that dialogue and collective construction must be present. It concludes that CRECE has a formative and articulating potential, revealing the nuances of a neighbourhood with an educating profile.
\end{abstract}

KEY WORDS: Council. Democratic Management. Participation. Educating City. Government-society relationship.

\title{
RESUMÉN
}

La gestión democrática de la escuela pública, principio constitucional brasileño, apuesta por la ciudad educadora a través del establecimiento de espacios democráticos de participación. El Consejo de Representantes de los Consejos Escolares (CRECE) es uno de estos espacios con potencial para articular acciones territoriales, promoviendo el diálogo entre las escuelas y entre estas y la estructura del sistema, presentando, debatiendo y deliberando sobre temas dirigidos a garantizar los derechos de los ciudadanos. Este texto proviene de una investigación académica que tuvo como objeto de estudio el CRECE y trata de la experiencia del CRECE en el barrio de São Mateus, localizado en la zona este de São Paulo. Tiene como objetivo presentar la articulación de las acciones democratizadoras y educativas realizadas entre las acciones del gobierno local y el mencionado consejo regional (CRECE) alineadas con la propuesta de la ciudad educadora. Para responder a la pregunta sobre cómo fue posible promover acciones articuladas entre el gobierno y la sociedad civil, la metodología empleada fue de tipo cualitativo, utilizando análisis de documentos y entrevistas (CELLARD, 2008; BOURDIEU, 2001). Teóricamente, fueron importantes las aportaciones de Paulo Freire, Luciana Tatagiba, Vitor Paro, entre otros. La experiencia reveló que, para la creación y fortalecimiento de espacios democráticos de participación en la ciudad como el CRECE, es necesario ir paso a paso, y que el diálogo y la construcción colectiva deben estar presentes. Concluye que el CRECE tiene un potencial formativo y articulador, revelando los matices de un barrio con perfil educativo.

PALABRAS CLAVE: Consejo. Gestión democrática. Participación. Ciudad educadora. Relación gobiernosociedad.

\section{CONSIDERAÇÕES INICIAIS}

No contexto dos anos 2000, pudemos assistir o aprofundamento das políticas neoliberais em escala globalizada. Capitaneando o discurso da almejada democracia, seus defensores pregam a importância do livre mercado, o ajuste fiscal como forma de sanear as contas públicas, o Estado mínimo, a redução das políticas sociais entendidas como nefastas aos cofres públicos, entre outras. Como consequências previsíveis, tem-se a construção do exército de desempregados, enfraquecimento dos sindicatos, desmobilização social, distanciamento da população das possibilidades de participação para definição das políticas públicas.

Revista de Ciências Humanas, Frederico Westphalen - RS, , v. 22, n.1, p. 13-41, jan./abr. 2021.

Recebido em: 09/04/2021 Aceito em: 02/06/2021


De forma internacionalizada, governos elaboram projetos e programas afinados a tais preceitos. No entanto, movimentos de resistência sempre existiram frente ao panorama que aponta perdas de direitos. São movimentos dessa natureza que tem forte expressão para tentar frear, coibir políticas que negam direitos aos trabalhadores, que promovem ações, formam redes, elaboram manifestos, cartas chamando a sociedade civil e poder público a reagir em prol da população. Nos anos 1990, vimos propagar a ideia da constituição de cidades educadoras que foi adquirindo adesões pelo mundo. Globalmente e também localmente, movimentos se multiplicam e se diversificam conforme o contexto, muitas vezes cravando avanços legais como aqueles registrados na Constituição Federal brasileira de 1988 (CF/1988), entre eles o princípio da Gestão Democrática (GD) no campo educacional, prevendo a criação de espaços democráticos de participação ativa.

Um destaque na CF/1988, foi para a Gestão Democrática como princípio no campo da educação, o que influenciou a ação de movimentos e governos comprometidos com práticas democráticas para além dos muros da escola, a se alinharem, em alguma medida, aos princípios da rede de Cidades Educadoras, alcançando estados e cidades, entre eles o estado de São Paulo, Rio Grande do Sul, Minas Gerais e cidades como São Paulo, Sorocaba, Santo André, São Bernardo do Campo. Entre tantas possivveis definições, pode-se entender que a Cidade Educadora é aquela que busca garantir direitos dos cidadãos, que os coloca como sujeitos ativos do lugar, ressignificando espaços e tempos, que cria espaços educativos para além da escola nos moldes formais, que tem a cidade como uma grande escola democrática, sendo importante a criação e recriação de espaços, fazeres que comprometam e envolvam governos e sociedade civil na construção da educação como processo infinito no tempo e no espaço com infinitas possibilidades, para além das descontinuidades de governos.

Nesse panorama, destaca-se aqui a construção e experiência do Conselho de Representantes dos Conselhos de Escola (CRECE) na cidade de São Paulo, uma cidade inscrita na rede de cidades educadoras. Esse conselho possui a característica marcante de ser regionalmente composto por representantes das escolas (funcionários e familiares dos estudantes). Sendo a escola o espaço do poder público mais próximo da população, ter um conselho com tal constituição traz relevância para a discussão de questões para além da escola, envolvendo a própria cidade.

O CRECE foi concebido no bojo das lutas entre as décadas 1970 e 1980. Militantes da área da saúde, moradia, pastoral da juventude, entre outros, lutavam pela criação de espaços de participação ativa no período marcado pelo fechamento político do país. Os avanços reconhecidos a partir dos conselhos de saúde influenciam militantes que também atuavam na área da educação impulsionando 0 
desejo e a necessidade da criação de um conselho regional de educação como espaço para o exercício da voz, de práticas democráticas da população.

No contexto pós CF/1988, a capital paulista elege Luiza Erundina como prefeita representando as propostas democráticas e populares do Partido dos Trabalhadores (PT). A participação popular, bem como a criação de espaços de participação passam a fazer parte da política da cidade. Os Conselhos de Escola (CE) com caráter deliberativo, proporcional, paritário torna-se realidade e desafio para a participação da população na definição dos rumos da escola. O CRECE surge também como demanda do CE e passa a ter suas primeiras experiências na cidade com interessante potencial agregador e formador (ARELARO; CABRAL, 2019; Autora, ano). Sem reconhecimento legal, na transitoriedade de governos, o CRECE é tirado de cena em 1993 e só volta a ser organizado de forma pontual na cidade em 2004, novamente num governo petista.

Este artigo aborda uma experiência dessa gestão (2001-2004), nesse período o CRECE não apareceu retratado no organograma da Secretaria Municipal de Educação (SME), nem nas reuniões e debates entre equipes do governo central e as equipes locais com sua devida importância, como espaço político de participação da comunidade escolar e local com potencial participativo e educativo. Contando com 13 instâncias regionais de educação ${ }^{3}$, o CRECE ressurgiu apenas em algumas regiões da cidade, a exemplo de bairros da zona leste e oeste da capital. Neste texto, focaremos na experiência desenvolvida num bairro da zona leste.

Sem registros acadêmicos que tenham como objeto de estudo o CRECE, o que também confere relevância de seu estudo, este artigo aborda resultado de pesquisa que teve como foco de investigação o CRECE em diferentes nuances. Tem por objetivo revelar, registrar as ações desenvolvidas pelo referido conselho em parceria com a Equipe de Gestão Democrática do NAE/Coordenadoria de Educação no bairro de São Mateus/SP e evidenciar essa articulação na perspectiva da cidade educadora. Para tanto, a pesquisa foi qualitativa a partir das contribuições de Cellard (2008) e Bourdieu (2001), sendo realizadas entrevistas com três integrantes da equipe que atuaram diretamente com o CRECE da região no momento e análise documental do período em tela. Para as análises, foram importantes autores como Vitor Paro que trata das relações de poder na educação, Luciana Tatagiba com suas análises sobre políticas de governo, entre outros.

O texto apresenta, nesta introdução, um breve panorama histórico do CRECE. Num segundo momento tece considerações sobre políticas públicas, cidade educadora e sua relação com a criação

3 Denominados Núcleos de ação Educativa (NAE), após a reforma administrativa da cidade transformados em 31 Coordenadorias de Educação, a partir da implementação das 31 Subprefeituras na capital paulista. 
de espaços democráticos de participação e formação como o CRECE; apresenta apontamentos sobre a proposta de gestão democrática no governo do PT (2001 - 2004); traz informações sobre o locus do estudo e a trajetória das experiências lá desenvolvidas pela equipe de governo local em parceria com o CRECE do bairro de São Mateus, São Paulo, Capital. Encerra ressaltando o papel do CRECE como espaço democrático de participação e formação no exercício democrático com a comunidade e governo local num bairro com desenvolvimento de ações consonantes com a perspectiva da Cidade Educadora.

\section{POLÍTICAS PÚBLICAS, CIDADE EDUCADORA E ESPAÇOS DEMOCRÁTICOS DE PARTICIPAÇÃO E FORMAÇÃO}

A criação de espaços democráticos de participação bem como a elaboração de propostas de formação e participação para os diferentes segmentos da escola e da sociedade, requer fazer escolhas, adotar certo posicionamento político. É construção coletiva e pode contribuir com a implementação de políticas públicas voltadas à garantia de direitos. Nesse sentido, "Políticas públicas são um tipo específico de ação política que [...] são definidas e praticadas em termos históricos" (DI GIOVANNI; NOGUEIRA, 2015, p. 19).

Em termos governamentais, a política pública como ferramenta vinculada às decisões do governo tem seu marco com a Guerra Fria, e também com a valorização da tecnocracia visando enfrentar suas consequências. Em 1948, nos Estados Unidos, foi criada a RAND Corporation, organização não-governamental, financiada por recursos públicos, tendo seu trabalho desenvolvido a partir de uma equipe multidisciplinar que envolvia estudiosos das áreas exatas e humanas que, influenciados pela teoria dos jogos, almejavam demonstrar que uma guerra poderia ser orientada como um jogo racional. A partir daí, "A proposta de aplicação de métodos científicos às formulações e às decisões do governo sobre problemas públicos se expande depois para outras áreas da produção governamental, inclusive para a política" (SOUZA, 2006, p. 4).

A definição do que se considera política pública foi adquirindo inúmeros contornos, não existindo, até hoje, uma única definição que abarque seu significado. Celina Souza (2003; 2006) recorre a vários autores no intento de traçar uma possível definição. Em linhas gerais, a autora traça duas perspectivas de estudo. Numa, as políticas públicas são definidas no sentido de associar as ações específicas de um governo com previsibilidade de efeitos também específicos, podendo essas ações serem viabilizadas diretamente pelo governo ou através de delegações, tendo a previsão que influenciem na vida das pessoas. Podem ser marcadas pelo que o governo escolhe ou não escolhe 
fazer. Nesse sentido, "[...] decisões e análises sobre política pública implicam responder às seguintes questões: quem ganha o quê, por quê e que diferença faz" (SOUZA, 2003, p. 13).

Por outro lado, críticos a essas definições consideradas exageradamente racionais e procedimentais das políticas públicas, ressaltam a importância de não se ignorar sua essência, a qual está atrelada às ideias e aos interesses, não devendo deixar de lado o seu aspecto conflituoso, bem como os limites e os condicionantes que estão imbricados nas decisões dos governos. Sendo assim, não podem deixar de ser considerados os grupos sociais e outras instituições. De um modo geral, essas definições ao assumirem uma perspectiva holística evidenciando a importância do todo em relação à soma das partes guiam nosso olhar, colocando sempre em foco os governos. Para Celina Souza:

\begin{abstract}
Pode-se, então, resumir o que seja política pública como o campo do conhecimento que busca, ao mesmo tempo, "colocar o governo em ação" e/ou analisar essa ação (variável independente) e, quando necessário, propor mudanças no rumo ou curso dessas ações e/ou entender por que e como as ações tomaram certo rumo em lugar de outro (variável dependente). Em outras palavras, o processo de formulação de política pública é aquele através do qual os governos traduzem seus propósitos em programas e ações, que produzirão resultados ou as mudanças desejadas no mundo real. (SOUZA, 2003, p. 13)
\end{abstract}

Nesse contexto, entende-se que

Os processos de mudança e transformação social nos quais se insere o cotidiano das sociedades contemporâneas constituem 0 marco de referência em que se encontram imersas as políticas públicas. Neste enquadramento, as cidades desempenham função primordial como entidades e organismos vivos e dentro delas a cidadania que lhe é outorgada. (AIEDA; ZUIN, 2012, 194)

O processo de formulação de política pública não se legitima sem ouvir as vozes daqueles diretamente envolvidos com as questões em pauta em um dado programa e/ou ação. Diante da complexidade do mundo real, que "encolheu" por ter se tornado mais conectado, adquiriu maior diversidade deixando de ser um todo ordenado a receber regras e normatizações (Giovanni; Nogueira, 2015, p. 31). Nesse sentido, é fundamental fomentar políticas públicas participativas que, como ativas, são também formativas, exigindo espaços, tempos, sujeitos para seu desenvolvimento. $\mathrm{Na}$ Cidade Educadora, as diferentes políticas, espaços, tempos e atores são concebidos como educadores com possibilidade de apoiar o desenvolvimento de todo potencial humano.

Ressalta-se ainda que, dentre outros, um "[...] objetivo da concepção de Cidade Educadora é dar à população o direito ao acesso às políticas públicas, ao mesmo tempo em que, possibilitaria um espaço de entrelaçamento de atividades de formação implicados na troca de saberes referentes ao mundo do trabalho e da cultura" (AIETA; ZUIN, 2012, p. 198-199) 
Entende-se que a ampliação de espaços democráticos de participação na cidade como 0 CRECE, concebido como política pública com potencial de articular sociedade civil e governo em torno de questões voltadas à garantia de direitos dos cidadãos, traduz-se em importante espaço de formação, visto que a prática participativa desenvolve inúmeros tipos de aprendizagens (AUTORA, 2012). É considerá-las como ações desenvolvidas no mundo da vida, no campo da educação não formal. Para além das escolas, as demais instituições participativas podem ser dotadas de potencial educativo. A perspectiva da Cidade Educadora afina-se com os princípios e objetivos da instituição CRECE. De acordo com a lei $n^{0} 16.213$, e o artigo $3^{\circ}$ do Decreto n. 56.520 , de outubro de $2015^{4}$ (SÃO PAULO, 2015a) tem-se que:

Art. $3^{\circ} \mathrm{A}$ atuação do CRECE será norteada pelos seguintes princípios:

I - democratização da gestão; || - democratização do acesso e permanência;

III - qualidade social da educação. (SÃO PAULO, 2015a)

Como objetivos, o decreto especifica:

Art. $4^{0}$ - São objetivos do CRECE:

I - articular a participação dos membros do Conselho de Escola para a construção e implementação do projeto político-pedagógico, respeitadas as diretrizes de SME, no que diz respeito ao processo de ensino-aprendizagem e ao cotidiano das unidades educacionais; II democratizar o acesso e a gestão dos espaços escolares e colegiados intermediários em uma perspectiva dialógica e de horizontalização das relações e de incentivo ao protagonismo infantil e juvenil, inclusive com a criação de grêmios estudantis ou outras formas de participação; III - fortalecer os Conselhos de Escola e a atuação da sociedade civil nas tomadas de decisão, compartilhando as responsabilidades na construção dos projetos político-pedagógicos das instâncias administrativas comprometidas com a qualidade social da educação; IV - consolidar a implementação de política estimuladora da participação e da socialização das informações, possibilitando qualificar as tomadas de decisão, por meio do resgate de diversos instrumentos e segmentos sociais que têm compromisso com as políticas de construção da escola pública, popular, democrática, laica e de qualidade para todos na Cidade de São Paulo. (SÃO PAULO, 2015)

A partir de seus princípios e objetivos, evidencia-se a importância da construção coletiva, da dialogicidade, da participação ativa, a gestão democrática tão relevantes para a construção da escola educadora, da cidade educadora. Nas considerações de Aieda e Zuin (2012, p. 199) a cidade educadora revela eixos de "articulação político-pedagógico e eixo de articulação políticoadministrativa". Para se garantir que esses eixos possam ser assumidos como espaço social da cidade, a exemplo do CRECE, faz-se necessário o exercício da dialogicidade por oferecer condições de proporcionar a inserção do cidadão na cidade, nos projetos políticos e educacionais em construção,

4 Após anos de muita luta e reivindicação para sua institucionalização, com o Movimento Pró-CRECE atuando desde 2005, o CRECE foi reconhecido legalmente como espaço político de participação com caráter deliberativo em 2015 pela Lei n. 16.213, de 17 de junho daquele ano. (SÃO PAULO, 2015b) 
visando o desenvolvimento da cidade em que comunidade e poder público atuem em consonância para a garantia de novas relações com o lugar. Ainda segundo Aieda e Zuin (2012, p. 209-211):

\begin{abstract}
Nesse alcance, a gestão democrática participativa é "aquela que se promove em conjunto", porque tem em seu bojo o campo da esfera comunicativa. Com esse processo, o campo da gestão democrática participativa passa a contemplar o cotidiano das pessoas e dos grupos sociais, assim como 0 uso das ferramentas da informação nos processos educativos na comunidade ou na cidade [...] Ao abordar a gestão participativa, é válido lembrar que não estamos limitando nossa análise às ações dos cidadãos, pois, apesar desse ser 0 responsável pelo processo comunicativo dentro da cidade, em um processo democrático participativo, a ação do governo faz parte do rol das ações educativas e educacionais da cidade, por ser o poder público responsável por administrar a política pública.
\end{abstract}

Com Paro (2012), entende-se administrar como escolher meios adequados para se atingir fins determinados, em tal sentido, meios não podem contradizer os fins. 0 poder público responsável por administrar a política pública deve garantir direitos da população e os meios escolhidos devem ser pela perspectiva democrática, dialógica, participativa.

\title{
APONTAMENTOS SOBRE A PROPOSTA DE GESTÃO DEMOCRÁTICA NO GOVERNO DO PT (2001 - 2004)
}

O Programa de Governo da administração do PT (2001 - 2004) apresentou para a educação, entre outras importantes medidas, o comprometimento com a questão da Gestão Democrática da educação e com a participação da população, afirmando que a busca do governo seria de "[...] aperfeiçoar os Conselhos de Escola e o Conselho Municipal de Educação, assim como reconstruir os Conselhos Regionais dos Conselhos de Escola (CRECEs) e incentivar a criação dos Grêmios Estudantis. (SILVA et al, 2004, p. 52-53)

Na prática, observou-se que no âmbito da política de governo, as constantes mudanças de secretários de educação, assim como das equipes da Secretaria Municipal de Educação podem ser entendidas como causas para a não efetivação desse princípio constitucional. Soma-se a isso, as diferentes concepções presentes sobre GD e participação da população nas tomadas de decisões sobre o bem público.

De acordo com Tatagiba e Teixeira (2006), o governo da então prefeita Marta (PT) investiu em espaços de participação como no Orçamento Participativo e na relação com a Subprefeitura. Nessa perspectiva, representantes da sociedade civil entrevistados pelas pesquisadoras, alegaram aumento de sua participação nesses espaços na região de São Mateus. No entanto, numa análise mais apurada dessa dinâmica, as autoras identificam essa participação pautada, porém, pela relação particularizada 
estabelecida com o subprefeito e com parlamentares que, focados no potencial mobilizador da região, dão continuidade à prática de loteamento de cargos diante das negociações com as forças políticas que pautam a governabilidade local.

Em nossa pesquisa, identificou-se, a partir de entrevistas, que o movimento do governo local era pautado pela adesão de pessoas para a atuação em prol de um político ou candidato. De acordo com dados da entrevista: "hoje o partido toca muito nisso, você tem que ganhar o voto da pessoa, tem que ganhar alguém para apoiar". Na verdade, aquele que se insere no grupo político local, sem se dar conta que está contrariando o princípio constitucional da GD, compromete a qualidade da participação, porque atende, a priori, apenas uma pessoa ou um grupo específico, distanciando-se do interesse coletivo como previsto pela gestão democrática participativa e pelos pressupostos da cidade educadora.

Para Silva et al (2004), em relação aos espaços democráticos de participação como o CRECE e os Conselhos de Escola (CE), revelou-se pouca atenção a eles na política educacional da gestão Marta (2001-2004). Isso pode ser constatado no início do governo, que optou politicamente por não resgatar ou não citar explicitamente a importância da democratização da gestão a partir do legado de Paulo Freire, não só como secretário de educação em momento histórico da capital paulista, mas, também, como intelectual reconhecido mundialmente.

As constantes trocas de secretários e desarticulação das equipes na SME trouxe, como um dos resultados possivelmente não esperados pela equipe de governo central, a efetiva descentralização das políticas educacionais. Nesse contexto, nos dois primeiros anos do governo, muitas ações foram encaminhadas regionalmente à revelia das orientações da SME, seguindo as concepções de integrantes das equipes locais, com diferentes propostas de acordo com cada região da cidade. No entanto, as ações encaminhadas no âmbito regional enfrentaram a atuação contrária da maioria dos supervisores de ensino e dos diretores de escola às propostas discutidas a partir da política educacional daquele governo. Segundo integrantes da coordenadoria de Educação da região pesquisada, diretores chegavam a rasgar e colocar no lixo do próprio NAE/Coordenadoria ${ }^{5}$ as propostas recebidas do governo, via panfletos ou circulares ${ }^{6}$. Havia a negação de informações para 0 grupo escola ou mesmo deturpação daquelas que eram repassadas, incluindo aí propostas articuladas com a cidade educadora. Poucos eram os diretores parceiros quanto aos encaminhamentos da

5 As 13 instâncias regionais de educação denominadas Núcleo de Ação Educativa (NAE), com a reforma administrativa da cidade que criou 31 Subprefeituras foram reorganizadas em 31 unidades regionais e denominação alterada para Coordenadorias de Educação (AUTORA, ANO).

6 Instrumento impresso adotado pelo órgão regional de educação municipal para envio de informes às escolas contendo informações sobre solicitações e encaminhamentos de cada setor da Coordenadoria. 
democratização da gestão escolar, comprometidos com a participação e formação da comunidade educativa para a construção da cidade educadora.

Nos dois primeiros anos do governo, um resultado positivo da desarticulação das ações da SME, diante de suas contradições que evidenciavam diferentes concepções para a GD, foi a descentralização da definição de ações voltadas à $\mathrm{GD}$, o que desencadeou certa autonomia pela equipe de $\mathrm{GD}^{7}$ para realização de propostas no âmbito local e nas escolas afinadas com o princípio constitucional da GD e com objetivos da Cidade Educadora. A partir de 2003, firma-se a secretária de Educação Maria Aparecida Perez e a nova equipe da SME é constituída, tentando evidenciar maior coerência e organização no encaminhamento das ações. Diante do tempo político provisório que marcam os governos (DOURADO, 2009), começam, ao mesmo tempo, a ser encaminhadas para as coordenadorias inúmeras ações interessantes envolvendo alunos, professores, escolas e comunidade, porém, sem articulação entre si, sem prévio debate ou tomada de decisão com as equipes das coordenadorias ou com representantes das escolas. Na verdade, ações encaminhadas de forma fragmentada e com caráter de visibilidade. Integrantes da SME de um setor não tinham informações sobre ações paralelas e afins encaminhadas por outros setores. Seus integrantes alegavam se tratarem de ações advindas diretamente pelo gabinete da então prefeita Marta Suplicy. Essas propostas, em grande medida, atropelavam os encaminhamentos construídos localmente no NAE/Coordenadoria, diante da falta de debate sobre seus objetivos e dificuldade de articulação com propostas em andamento como a construção de espaços democráticos de participação, da Cidade Educadora e a Rede de Proteção Social. Foi possível identificar alguns Projetos da Cidade Educadora - São Paulo- SP, como:

\footnotetext{
Avanços na construção da qualidade social a educação; A educação e a rede de proteção social; CEU - Centro Educacional Unificado; A gestão e a organização da escola em ciclos; Programa de formação e acompanhamento: "programa de reorientação curricular na educação básica", "cidade educadora-educação inclusiva: um sonho impossível": CECl- Centro de Educação e Cultura Indígena; Projeto Escola Aberta; Projeto Educom.Rádio; Projeto Recreio nas férias; Programas sociais Renda Mínima, Bolsa Trabalho e Começar de Novo (AIETA; ZUIN, 2012, p. 222-223, grifo nosso)
}

Nenhuma dessas ações tão diversificadas eram discutidas no sentido do fortalecimento dos conselhos de escola ou do CRECE, como constava no Programa de Governo, o que conferiu ao

7 A constituição de uma equipe específica para tratar das ações sobre democratização da escola e sua relação com a comunidade educativa e local foi uma opção política. Infere-se que diante das diferentes concepções presentes nas instâncias regionais e, também, na SME, a constituição de tal equipe não aconteceu em todas as regiões da cidade. 
governo local de algumas regiões com histórico de participação popular na defesa do bem público na área da educação, a investir na construção de propostas de GD localmente articulando-as aos princípios e objetivos da Cidade Educadora, como as desenvolvidas no Bairro de São Mateus, SP/SP, que serão apresentadas mais adiante.

\section{O bairro de São Mateus - SP}

Localizado na zona leste/sudeste, a $20 \mathrm{~km}$ do centro da capital paulista, em uma região que tem proximidade com os municípios de Mauá, Santo André, Ribeirão Pires, região do $A B C^{8}$ da grande São Paulo, o bairro de São Mateus está formado por três distritos. Em 2001, o distrito de Iguatemi contava com uma área de $19.57 \mathrm{~km}^{2}$ e uma população de 128,723 habitantes; o distrito de São Rafael contava com área de $13.1 \mathrm{~km}^{2}$ e uma população de 148,778 habitantes e o distrito de São Mateus com área de $12.83 \mathrm{~km}^{2}$ e uma população de 158,828 habitantes, perfazendo um total de área correspondente a $45.5 \mathrm{~km}$ e 1.596,329 habitantes ${ }^{9}$. A proximidade com a região do $A B C$ vai além da geografia. De acordo com o portal da prefeitura, "Esforço e dedicação sempre estiveram presentes na História da Cidade de São Mateus". Afirma ainda se tratar de "Um bairro que nasceu e cresceu através das lutas populares. Aqui, pessoas de credos, raças e tendências políticas, das mais diversas, se reuniram num só objetivo: Transformar este lugar da Zona Leste da Capital num bairro de fato. (SÃO PAULO, 2010)

Tendo loteamento iniciado por volta de 1948, já no início da década de 1950, os moradores se organizaram para pedir melhorias. Primeiro, pediram escolas, iluminação e transporte. Depois, a luta foi pela implantação do asfalto, redes de água e esgoto, iluminação pública e outros serviços, como delegacias e agência dos Correios.

A construção da primeira escola foi fruto de luta árdua dos moradores, uma vez que as crianças andavam aproximadamente $7 \mathrm{~km}$ para chegar na escola mais próxima. Em 1952, o estupro de uma criança de 10 anos parece ter sido a gota d'água para que a luta pela construção de escolas nas proximidades começasse. O resultado só apareceu em 1955, com a construção de um galpão de

80 bairro de São Mateus localizado na capital paulista uma cidade educadora, tem como vizinhos os municípios da região do Grande $A B C D$, na qual encontramos Santo André e São Bernardo do Campo inscritos como Cidades Educadoras (AIEDA; ZUIN, 2012)

${ }^{9}$ Disponível em:

$<$ https://www.prefeitura.sp.gov.br/cidade/secretarias/subprefeituras/sao_mateus/historico/index.php?p=438>. Acesso em: 20 dez. 2018. 
madeira feito pela Secretaria da Educação e Cultura do estado ${ }^{10}$. Muitas histórias de luta marcam a região de São Mateus, entre elas a luta pela ampliação do número de escolas e por espaços de participação da população para reivindicação das demandas e atuação nas tomadas de decisões do bairro.

Em 2001, o NAE de São Mateus contava com 27 EMEFs, 22 EMEls, 20 Creches diretas, 22 creches conveniadas, 1 escola de EJA. Algumas dessas unidades escolares eram localizadas em ruas sem pavimentação, iluminação e distante dos meios de transporte e em número insuficiente para 0 atendimento à demanda. ${ }^{11}$ Nessa mesma época, no NAE de São Mateus, a equipe específica que estimularia as diferentes ações com o intuito de aproximação escola-comunidade, foi constituída desde o primeiro dia do governo da administração do PT na região como uma opção política. A preocupação da equipe era com o processo formativo e a articulação de ações democratizantes, inclusive dentro da estrutura do NAE. Propuseram ao então coordenador a constituição de uma gestão colegiada para 0 próprio NAE, ressaltando que a "Democratização da gestão da escola e do sistema", como diretriz a ser seguida conforme Plano preliminar da SME, exigia ousar em novas ações com potencial formativo. No entanto, também por divergência de concepções de gestão com a coordenação do NAE, SME, Gabinete e, possivelmente, de orientações de grupos do partido, a proposta não foi considerada. 0 modelo aceito, defendido e colocado em prática era aquele: hierárquico, vertical e centralizado, revelando, em certa medida, a perspectiva de GD adotada por integrantes do governo em pauta. A gestão colegiada pressupõe rompimento com as amarras burocratizantes que, em nome de atendimento às regras e normas, truncam processos democráticos.

No NAE da região de São Mateus, a equipe de GD manteve ao longo do período de sua atuação (2001 a 2004) estreito relacionamento com a equipe responsável pelas propostas pedagógicas, trabalhou conjuntamente em definições conceituais e com elaborações de propostas com e para as escolas e comunidade, proporcionava debates, embates, problematizações, controvérsias e enfrentamentos com boa parte da equipe de supervisão, que pela posição hierárquica, se considerava a única equipe legítima e credenciada a fazer o contato direto com a escola e comunidade. As propostas em atendimento à diretriz GD da escola e do sistema, imbricadas com as demais diretrizes (qualidade social da educação e da garantia do acesso e permanência) bem como com os objetivos da cidade educadora, passaram a ser traçadas para e com a comunidade educativa, notando que contraditoriamente, àquelas correlatas à democratização do sistema não tinham espaço para discussão

10 A rede municipal de ensino de São Paulo foi criada em 1956.

11 A população residente em idade de 0 a 15 anos era de 119.740 (SANTOS; BARRETTA, 2004).

Revista de Ciências Humanas, Frederico Westphalen - RS, , v. 22, n.1, p. 13-41, jan./abr. 2021.

Recebido em: 09/04/2021 Aceito em: 02/06/2021 
no próprio sistema (AUTORA, ANO). A equipe de GD desencadeou uma série de ações articuladas, que se apresenta abaixo.

\section{DEMOCRATIZAÇÃO DA GESTÃO: O CRECE E A ESPECIFICIDADE DO BAIRRO DE SÃO MATEUS/SP}

O setor de GD em São Mateus foi composto, inicialmente, por duas pessoas. Posteriormente, com o aumento do número de ações, duas outras passaram a integrar o grupo. Após o setor ser transformado em Programas Especiais (em 2002), para manter as ações em andamento e atender aquelas proporcionadas pelo governo central (SME e Gabinete da Prefeita), a equipe recebe mais três pessoas, perfazendo um total de sete pessoas, a partir da metade do governo, três delas, dedicadas ao CRECE entre inúmeras outras ações.

Dotada de certa autonomia, tanto na relação com a SME, quanto naquela estabelecida com a coordenação regional ${ }^{12}$, contando com 0 apoio desta, foram desenvolvidas ações descentralizadas com foco na participação da comunidade escolar e local diante da importância da democratização das relações, bem como na tomada de decisões como propõe a LDB/1996 e a opção da perspectiva freiriana de ação. A retomada do CRECE foi colocada como uma das prioridades, vislumbrando sua articulação com as demais ações na perspectiva da GD, da territorialidade, da Cidade Educadora. No entanto, era necessário preparar o terreno para o desenvolvimento da proposta, sendo uma delas a retomada do debate a questão dos encaminhamentos voltados ao Conselho de Escola. Nesse sentido, de acordo com o Livro de Ata de Registros de fevereiro de 2001, realizou-se a primeira reunião com diretores das unidades escolares, e contou com a presença dos supervisores, que teve como pauta "Retomando a conversa com Paulo Freire" tendo como referência seu importante legado para a educação. Por ocasião, utilizou-se trechos de escritos freireanos (FREIRE; 1979; 1991; 1993), bem como no livro "Aceita um Conselho", de Angela Antunes, e a legislação sobre a democratização da gestão escolar. No confronto entre o paradigma vigente e o paradigma emergente, como explicitado por Bordignon e Gracindo (2009), ouvia-se de alguns diretores: "vocês pensam que estivemos dormindo esses oito anos de governo que se passaram?", "Essa discussão de Paulo Freire está ultrapassada. Estamos em outros tempos", "a democratização da gestão da escola já está consolidada e isso é coisa do passado". Esse tipo de reação revelava o temor, por parte de diretores, de perderem

12 Enéas Carvalho foi o primeiro Coordenador Regional de Educação, sendo substituído a partir do segundo ano por Dalva Souza Franco que permaneceu até 2004. 
o falso poder na estrutura hierárquica do sistema, em negar a possibilidade de participação do cidadão como governante prevista na CF/1988.

No contraditório, uma supervisora presente se manifestou dizendo: "se tudo isso já está conversado e consolidado onde estão os Grêmios Estudantis atuantes nas nossas escolas? Afinal, se temos alunos nos Conselhos de Escola, quantos deles adquiriram condições de mobilização e tiveram a oportunidade de desencadear a constituição dos Grêmios nas nossas escolas?" (AUTORA, ANO). Essa postura parecia evidenciar certa inquietação entre o paradigma vigente e 0 emergente (BORDIGNON E GRACINDO, 2009), entre a possibilidade de continuidade ou de ruptura de encaminhamentos da coisa pública. As manifestações hostis reforçavam a necessidade do debate sobre a questão da democracia na escola.

As entrevistas e os registros de atas das reuniões realizadas pela equipe do NAE, evidenciam os desafios impostos diante da estrutura autoritária, hierarquizada e centralizadora vigente. Vislumbrando superar esse panorama, ações foram traçadas coletivamente envolvendo poder público e representantes do CRECE (AUTORA, ANO).

Primeiros passos: democratização da gestão da educação no âmbito do bairro

Palestras sobre educação e prática democrática foram viabilizadas, com a presença do Prof. Dr. Vitor Henrique Paro, a qual foi acompanhada por professores, diretores e supervisores do NAE de São Mateus e com representantes de outros NAEs da cidade, interessados na discussão. A palestra consistiu em discutir educação e democracia, a construção do humano, sujeito, histórico, social e político e os desafios para a administração escolar democrática (PARO, 2012). Notou-se que passados 13 anos da promulgação da CF/1988, cinco anos da LDB/1996, discutir as leis nas propostas formativas e autores como Paulo Freire, Vitor Paro, Ângela Antunes, sobre democratização da gestão escolar, surgiam como ameaça ao autoritarismo vigente.

Seguiram-se debates e embates com diretores avessos a processos participativos. Eles contavam com o apoio de vários supervisores contrários a qualquer proposta da administração petista, entre elas a reconstrução do CRECE, considerada como interferência desnecessária diante de suas ações supervisoras e de direção em curso. As propostas, entendidas como democratizantes pela equipe do governo local, eram interpretadas por supervisores e diretores como autoritárias, ou seja, intromissão na sua "autonomia" de conduzir o destino da escola, uma vez que faziam parte de um governo que eles combatiam. A defesa de direitos, a contestação de privilégios, o investimento na transparência nas ações e nas tomadas de decisões, a ocupação da escola pela comunidade, eram por 
eles avaliadas como encaminhamentos autoritários. A construção coletiva na escola, a descentralização do poder, a necessidade de mudar o eixo do debate da autocracia pela democracia apresentava-se como emergente nas ações cotidianas das escolas e do NAE.

Para a equipe de GD, atuar com supervisores e diretores, maioria concursados, defensores da hierarquização, do centralismo, das relações de mando, avessos à participação da comunidade na escola, fazia parte do cenário diário da construção coletiva da democratização da gestão da escola e do sistema. Nos dizeres de Paro (2008), educação é processo e como tal, não se constitui em certeza; nesse processo a pessoa pode convencer ou ser convencida. Relações de poder estão presentes e sua constituição com o outro pode proporcionar o empoderamento de ambos, contrapondo-se, assim, à perspectiva da relação de poder de uns sobre outros.

A partir do princípio constitucional da GD, das orientações do Regimento Escolar, que em grande medida copiou o Regimento Comum das Escolas Municipais de 1992 e do que propunha 0 Programa de Governo para 2001 - 2004, a proposta de formação dos CEs deveria trazer inovações práticas. Enfatizou-se a divulgação da importância da constituição de CE a partir de assembleias como constante no Regimento Escolar, documento norteador de cada unidade escolar. Esse regimento já não continha mais a alusão para o CE indicar representantes para a formação do CRECE.

Tendo em vista a reconstituiçãa $0^{13}$ do CRECE na região, a sua importância para o debate da cidade educadora articulado à gestão democrática e participativa, a necessidade de evidenciar fortalecer o CE fez-se urgente. Foi desencadeado um processo de visibilidade do CE, de suas ações e atribuições, de seus conselheiros e do seu presidente.

Segundos passos: construindo o pré-CRECE

Constituiu-se a comissão pré-CRECE, incluindo representantes das escolas (professores e pais). Ela se encarregou de preparar e divulgar cartazes para todas as escolas da região, em número suficiente para afixá-los em seus diferentes espaços com potencial educador, inclusive para fora do espaço escolar, envolvendo o comércio local, igrejas, associações comunitárias, dinâmica que poderia trazer contribuições também para a reconstrução do CRECE na região.

Essa comissão, em parceria com a Equipe de GD do NAE, solicitou para as escolas o nome de pessoas que, além do diretor, pudessem ficar responsáveis pela divulgação do material e acompanhamento do processo eleitoral do CE. A equipe de GD do NAE e a comissão se colocaram à

13A região contou com CRECE na administração do PT (1989 - 1992). Na ocasião, o CRECE fazia parte da organização regional da educação NAE 9 (AUTORA, ANO). 
disposição para visitas de esclarecimento e apoio ao processo eleitoral. Essa era uma forma de contemplar as demandas apresentadas por familiares dos estudantes e militantes, em defesa da participação como condição para a democracia na escola.

Constituídos os CE e desfeita a comissão, a eleição de representantes do CRECE foi colocada como proposta para as escolas. Diante das dificuldades enfrentadas com vários diretores escolares, a equipe de GD do NAE realizou um cadastro dos conselheiros escolares para uma comunicação mais direta, via telefone, e-mail e mala direta (na ocasião, não se contava com a facilidade de acesso a emails nem whatsapp para difusão das informações). Após o estabelecimento do canal direto de comunicação com os conselheiros, o que não excluiu o envolvimento da direção das escolas, realizouse o levantamento dos nomes indicados pelo CE para atuar como representante no CRECE, a solicitação de propostas de temas para a realização do curso de formação dos conselheiros escolares e do CRECE e um questionário foi enviado solicitando sugestões dos conselheiros.

Quanto ao curso, com a devolutiva dos questionários que apresentavam temáticas em torno da questão da participação, relações de poder na escola e na sociedade, formas de resistência, foi possível planejar, organizar e criar as condições para a sua realização com Conselheiros de Escola e do futuro CRECE. Essas ações foram desenvolvidas em escolas, espaços da Sociedade Amigos de Bairro, nos espaços do SESC Itaquera e, após 2003, nos Centros Educacionais Unificados (CEUs) ${ }^{14}$, dada a amplitude de seu espaço e ser espaço público. Providenciou-se almoço para os participantes, já que os encontros foram realizados em dois dias, com oito horas de duração por dia.

De posse da lista de interessados que envolvia pais, mães, alunos da Educação de Jovens e Adultos (EJA), professores, coordenadores pedagógicos, pessoal de apoio à ação educativa e direção escolar, procurou-se por pessoas com reconhecida atuação na área de formação política em movimentos sociais, sindicatos, partidos políticos, que tivessem afinidade com a educação e que atendesse às expectativas dos conselheiros, do programa de governo e da equipe de gestão democrática local. 0 conteúdo programático, as turmas, os espaços e o almoço para os participantes foram organizados. As inscrições recebidas para o primeiro curso, cujo tema centralizava a importância

14 Concebido na perspectiva da Cidade Educadora, o CEU foi criado na administração petista (2001 - 2004). É um espaço que educativo formado por unidades educacionais (Centro de Educação Infantil-CEI, Escola Municipal de Educação Infantil-EMEI, Escola Municipal de Ensino Fundamental-EMEF; Centro de Esporte e Lazer e Centro de Atividades Culturais. Atende crianças e adolescentes matriculadas nas suas dependências escolares, bem como de toda a região e da cidade em ações voltadas ao esporte e lazer e cultura. 
da Comunicação e Expressão, foi direcionado a partir da questão: ser tímido ou intimidado quanto ao processo participativo? ${ }^{15}$

Pautado na relação de poder, o curso tinha como objetivo vivenciar dinâmicas que demonstrassem a possibilidade de transformação do poder sobre o outro para o poder com o outro (FREIRE, 1979; 1991;1993; PARO, 2008). Em outras palavras, o foco estaria no modo como o discurso que evidencia o ser tímido, cria e esconde o ser intimidado; como se constrói o mecanismo da inibição das pessoas por meio da coerção, a importância do exercício da voz enquanto poder de decisão. Os cursos aconteceram durante dois dias inteiros consecutivos (sábado e domingo), com 8h de duração em cada dia, tinha um compromisso com a construção coletiva, contando com aproximadamente 25 a 30 participantes que, por vezes, traziam seus filhos. As temáticas foram: a. Comunicação e Expressão; b. Classe - A organização social capitalista; c. Relações de Gênero e poder; d. Relações Étnico-Raciais e poder. A dinâmica dos cursos era pautada em debates, análise de situações-problema, análise crítica de vídeos; músicas; dinâmicas de grupo; círculo de discussão envolvendo tomadas de decisões; encenações envolvendo situações de representações sociais e escolares; organização de painéis comparativos; pesquisa de observação de situações cotidianas da escola e de registros escolares. 0 curso, como um meio para atingir fins determinados (PARO, 2012), sobre como instrumentalizar os conselheiros escolares e do CRECE e demais interessados a participar da tomada de decisões da escola, ocorreu durante os quatro anos do governo e, de acordo com as atas de registro de avaliação dos cursos, repercutindo positivamente entre os conselheiros.

Paralelamente, os encontros pré-CRECE foram organizados e realizados por polos na região de São Mateus. Eram cinco e neles, também, aconteciam propostas formativas por meio de oficinas, representação teatral, jogos, que problematizavam a questão do orçamento no município, na escola e na vida, bem como debates articulados com a proposta do Orçamento Participativo. Eram discutidas questões sobre a segurança nas escolas e do bairro, propostas pedagógicas, relações de poder, entre outras, conforme atas de registro das reuniões $2001-2004$.

Terceiros passos: consolidação do CRECE e a importância da constituição de comissões

O movimento pré-CRECE foi importante para a divulgação, organização, constituição e reconhecimento desse conselho regional. Definidos os polos, as reuniões do CRECE eram realizadas, de forma sistemática, em escolas das cinco regiões de São Paulo e ocorriam à noite. $O$ ciclo contava

15Para o desenvolvimento desse curso contamos com a parceria com o Núcleo Treze de Maio. Grupo constituído por militantes, pesquisadores e estudiosos de esquerda, que organizam propostas de formação política, tendo atuado junto a movimentos sociais, sindicatos, Partido dos Trabalhadores, entre outros. 
com um encontro em cada região por semana, o que significava uma verdadeira maratona de encontros dos micro CRECEs, visando serem realizadas o mais perto possível dos conselheiros. De acordo com as entrevistas, esse espaço aproximou os participantes, favoreceu o desenvolvimento de debates sobre encaminhamentos inadequados ocorridos nas escolas, envolvendo uso de verbas públicas, cobranças de taxas indevidas aos pais, sobre a qualidade do atendimento do transporte escolar gratuito ${ }^{16}$ e a necessidade da constituição de comissões de atuação quanto ao acompanhamento às demandas das escolas e mesmo da região como segurança e transporte (AUTOR, ANO).

Fez parte do debate no CRECE a abertura das escolas em fins de semana realizada com todas as escolas. A princípio contou com a adesão de duas escolas, de um total de 50 unidades escolares (27 EMEFs e 23 EMEls). A proposta era a realização de oficinas, atividades culturais, esportivas e educativas, com ou sem a presença de funcionários, professores ou direção da escola, cabendo à comunidade escolar definir a melhor forma de encaminhamento, prevendo-se que, na etapa inicial, seria necessária a presença de alguém da equipe escolar, questão acompanhada por uma comissão do CRECE.

A intenção era formar parceria com as áreas da saúde, esporte, cultura do município para a realização de atividades educativas, culturais, lazer e esporte, na perspectiva da cidade educadora, 0 que na prática não se confirmou, ficando, em grande medida, a cargo da equipe do NAE encontrar estratégias para a realização dessas ações. A proposta debatida no CRECE era de, inicialmente, envolver voluntários, pessoas atuantes nos movimentos de cultura, saúde, esporte da região e, posteriormente, com contratações de oficineiros autorizados pela SME. Naquele momento, os participantes do CRECE incentivaram os voluntários da região a fazer suas inscrições para possíveis contratos $^{17}$.

Discutido no CRECE, foi adotado no NAE, como critério para a contratação de oficineiros para o Projeto Escola Aberta, que a escola deveria definir coletivamente qual seria a sua necessidade, cujas propostas deveriam ser apresentadas e debatidas no $\mathrm{CE}$, que daria seu parecer para a contratação. 0 oficineiro, além da habilidade específica do seu campo de atuação, precisava ter uma relação estreita em ações participativas com a escola ou comunidade local. Os participantes contemplados pelos CEs foram, posteriormente, indicados para atuar nos CEUs da região.

As reuniões no CRECE discutiam que a abertura da escola não restringisse aos horários de

16 Na ocasião, chamado "Vai e Volta", posteriormente (2005) denominado TEG (Transporte Escolar Gratuito). 17 Nessa ação existia divergência de concepção entre equipe do NAE e da SME, quanto aos encaminhamentos adotados para contratação, sobre o que era trabalhar com a proposta 
aula. Deveriam abordar a perspectiva de atividades educativas que remetessem às questões de classe, gênero, etnia e geração. Ao tecer argumentos por escolas democráticas, Apple e Beane (2001, p. 17) enfatizam a importância da "[...] organização de instituições sociais para promover e ampliar o modo de vida democrática". Com esse propósito, o CRECE aprovou o I Encontro Regional de Escolas Abertas. Os objetivos do encontro eram: trocar experiências entre escolas; debater sobre a importância da constituição de espaços democráticos de participação na região; enfatizar que escola não se restringe ao prédio, devendo abarcar sua estrutura e organização como grupo social na cidade. Destacou-se, também, ações das escolas, do NAE/Coordenadoria e do CRECE em andamento. Houve a constituição de mesas de debates e palestras com estudiosos e ativistas de questões sociais, além das citadas acima, ampliando o debate, ao abordar a questão da sexualidade, homoafetividade e da deficiência física na relação ao acesso à cidade. Ainda fez parte do encontro a apresentação de atividades culturais desenvolvidas pelos alunos da região e exposição de artesanatos confeccionados por artesãos pais e membros da região.

Para a realização desse encontro, as escolas parceiras contribuíram com a doação de alimentação e uma equipe de, aproximadamente, vinte e cinco mães voluntárias ${ }^{18}$, várias integrantes do CRECE, que se organizaram e prepararam o almoço para cerca de 400 pessoas presentes, em uma demonstração de interessante construção coletiva em prol dos estudantes da região. Essas ações, entre outras, contavam com participação ativa de integrantes do CRECE por meio de comissões. A implantação e encaminhamentos adotados pelos CEUs ilustra a importância dessa atuação em um trabalho constituído coletivamente. De acordo com Silva e outros (2004, p. 54) que analisaram a evolução das políticas públicas no Município de São Paulo no governo Marta Suplicy, as entrevistas e os registros realizados revelaram que o NAE 13 (São Mateus), por exemplo, optou por rearticular os CRECEs e, a partir deles, constituiu comissões sobre temas diversos de maneira a facilitar 0 monitoramento das políticas educacionais implementadas na região e propor ações. Essa estrutura, segundo a equipe do NAE, vinha apresentando interessantes resultados na implantação do CEU São Mateus. A partir dos CRECEs foram constituídas comissões que discutiram com representantes da administração o futuro funcionamento da unidade.

Encaminhamentos específicos da equipe de GD do NAE, com a atuação do CRECE também foram desenvolvidas nas ações correlatas à implantação dos dois CEUs da região: o CEU São Mateus e o CEU São Rafael. O advento do CEU trouxe inúmeras discussões entre Coordenadoria e

18Nessa ocasião, o CEU São Mateus contou com um Conselho de Voluntários atuantes para muito além dos horários de funcionamento das suas unidades escolares. 
comunidade com participação do CRECE sobre as possibilidades de mobilizações da população para a sua implantação. Em diversos momentos, os encaminhamentos traçados pelo Gabinete da Prefeita ou da SME foram reelaborados; por exemplo, quando da constituição do processo eleitoral para a eleição do gestor do CEU, em que seguiram-se as orientações apresentadas no Diário Oficial. Após o recebimento das inscrições dos interessados, organizou-se sua apresentação para a população em um evento realizado em uma escola do entorno, em que seria instalado o referido CEU.

Alguns candidatos, após ampla discussão, resolveram montar uma chapa, apresentando-a para a população com o slogan "Abrir as portas do CEU", em referência a torná-lo um espaço construído com e para a comunidade. Em seus discursos afirmaram: "essa será a nossa proposta, independente do candidato desta chapa que venha a vencer essa eleição" (discurso proferido pelos candidatos em 2002, numa quadra de esportes de uma EMEF da região). O processo eleitoral contou com urnas, literalmente transparentes com a apuração de votos realizada em clima de grande pleito ${ }^{19}$. Também foi possível destacar a atuação da equipe da Coordenadoria junto às ações desenvolvidas no CEU, a saber: a constituição de um Conselho de Voluntários, que atuou ativamente em parceria com o Conselho Gestor do CEU, envolvendo-se em ações de organização, segurança, divulgação referente ao que ia ocorrendo no CEU; contratação de deficientes físicos para atuarem como monitores de atividades recreativas. Iniciadas as atividades do CEU, a comunidade constituiu um Conselho de Voluntários do CEU São Mateus, equipe composta por 25 pessoas da comunidade que atuaram de forma articulada com o Conselho Gestor, ações acompanhadas pela equipe de GD e o CRECE (como a ação sobre o Encontro Escola Aberta citado acima).

Paralelamente, a Equipe de GD discutia com a equipe pedagógica, com as comissões do CRECE e com seus conselheiros, a necessidade de desencadear proposta de relações democratizantes na ação pedagógica. Na perspectiva defendida por Paro (2011), essa questão seria importante constar na formação dos professores, pois as ações administrativas são indissociáveis das ações pedagógicas; o funcionamento da escola e as questões pedagógicas fazem parte da estrutura.

19 Contraditoriamente, a SME e Gabinete, solicitou lista tríplice para posterior escolha do nome pelo órgão superior, não sendo escolhido para o cargo de gestor o primeiro lugar eleito pela população. 0 cargo foi ocupado pelo segundo colocado, vindo a exercer ações com total prioridade para a participação da comunidade na instituição. Destacamos que o escolhido pelas instâncias superiores, como gestor do CEU era, até então, membro da equipe de Gestão Democrática da Coordenadoria de São Mateus que, a partir de 2002, insatisfeito com os encaminhamentos adotados por SME e Gabinete, diante do desafio e discurso que permeavam a proposta de implantação do CEU, com ênfase na participação da comunidade, resolveu candidatar-se ao cargo de Gestor. Para a ocupação de tal cargo, para surpresa de todos que participaram daquele processo, não exigia ser diretor de escola, como esperado por muitos; bastava ser professor da rede municipal. Isso, também, se traduziu em desafio para os candidatos, pois parecia romper com hierarquias naturalizadas e concebidas na rede.

Revista de Ciências Humanas, Frederico Westphalen - RS, , v. 22, n.1, p. 13-41, jan./abr. 2021.

Recebido em: 09/04/2021 Aceito em: 02/06/2021


Foi realizada formação envolvendo concepção de educação, de gestão/administração20 e de atendimento às crianças, pensadas também para os condutores dos transportes escolares gratuitos, diretores e mães numa perspectiva de educação da cidade.

Outra ação formativa com aprovação do CRECE, foi a formação e construção da atuação diária nas escolas dos jovens que cumpriam medidas sócio educativas, transformando-os em "Agentes Comunitários", responsáveis por ações educativas, culturais e esportivas diversas com alunos e comunidade de algumas escolas parceiras. Esses "Agentes Comunitários" eram jovens que faziam parte de um programa social que oferecia bolsa a jovens carentes ${ }^{21}$ muitos deles ex-alunos, expulsos das escolas da região. Diante do desempenho dos jovens, outras escolas passaram a solicitá-los.

Tendo em vista a importância do protagonismo infantil e juvenil e da participação dos alunos no processo de democratização da gestão escolar, questão debatida no CRECE, a Equipe de GD com a comissão do CRECE, promoveu as condições para o I Encontro de Estudantes da Região, que deveria ser totalmente pensado e organizado pelos próprios alunos. A participação dos adultos deveria ocorrer apenas na viabilização da infraestrutura como: alimentação, transporte, equipamentos de som, solicitação de espaço, autorização dos pais, contato entre as escolas, entre outros, demandas encaminhadas pela comissão do CRECE.

A partir do contato com as escolas, geralmente por meio de um professor ou da coordenadora pedagógica, foi proposto aos alunos escolherem alguns representantes que comporiam uma comissão de alunos encarregada de pensar "politicamente" o I Encontro de Estudantes, cujo objetivo era desencadear a formação dos Grêmios nas escolas. Nos registros das ações há o encaminhamento para que uma coordenadora pedagógica ou um professor trouxesse os alunos eleitos para uma escola polo para o debate que, ao serem reunidos traçariam as estratégias do que achavam importante para a realização do Encontro. Ao final de cada reunião, suas dúvidas, solicitações e opiniões eram reportadas para a equipe de GD e à comissão do CRECE, que as levavam às reuniões do CRECE. Ônibus foram contratados pelo NAE, garantido um roteiro para seu percurso, o qual deveria passar por

20 Contrapondo-se a Heloísa Luck (2006), em Paro (1997; 2000), o termo gestão pode ser utilizado como sinônimo de administração que, como a escolha de meios para se atingir fins determinados, podem trazer conotações autoritárias ou democráticas, não sendo necessariamente o nome que determina sua concepção.

210 governo desenvolveu, junto à população pobre, os chamados Programas Sociais que previam bolsa com um determinado valor a ser recebido pelo inscrito e contemplado, devendo este passar por processos formativos para sua devida efetivação do Programa. No entanto, o que se pode perceber é que os jovens que participaram do Programa tinham dificuldades de acesso a algum processo formativo. Não tendo dinheiro para o transporte para acessar outras possibilidades de formação fora do bairro, viam-se limitados e ociosos em suas atribuições como bolsistas. Em muitos casos, tratavam-se de jovens, adolescentes, menores de dezessete anos, que tinham sido expulsos ou abandonado a escola, com ensino fundamental ou ensino médio incompletos, desempregados de famílias pobres, vários com dificuldade de ter até alimentação em casa. 
escolas polo, por região, a fim de transportar os alunos até o local do evento. $O$ almoço foi garantido com o auxílio de algumas escolas parceiras que forneceram alimentos (AUTORA, ANO).

Em conformidade com os registros das atas, os encontros ocorreram em duas edições. No primeiro encontro, participaram representantes das entidades estudantis UMES, UBES, UPES, Grupo Força Ativa ${ }^{22}$ e de antigos militantes do movimento estudantil da década de 1960 e 1970, que fizeram seus depoimentos sobre ser militantes no período da ditadura e sobre as possibilidades de atuar em movimentos estudantis na atualidade. O Encontro foi enriquecido, também, com apresentações de grupos musicais e grupos de debates entre os adolescentes. A atuação de conselheiros do CRECE residiu no cuidado com a infraestrutura e apreciação do desenrolar das ações do evento.

No II Encontro de Estudantes, com duração de um dia, o esquema de organização se repetiu. Os jovens se organizaram em salas de debates, onde discutiram as dificuldades, incoerências e possibilidades para a formação dos grêmios em escolas que ainda eram constituídos. Por ocasião, a questão da sexualidade dos adolescentes também foi abordada. O CRECE acompanhou o movimento dos estudantes, avaliando-o como revelador de potencialidades dos adolescentes.

Outra ação que teve importante atuação do CRECE por meio da ação de uma comissão por ele designada, foi aquela relacionada com o oferecimento do Vai e Volta, (atualmente Transporte Escolar Gratuito - TEG) aos alunos residentes longe da escola. Essa proposta desencadeou diversos problemas acompanhados de perto pela referida comissão. Em decorrência da contratação insuficiente de condutores escolares, atrelados às cooperativas ou que, de forma autônoma, conseguiam firmar contrato, deveriam entrar em contato com as escolas para receber a lista dos alunos a serem atendidos.

Muitas escolas, diante da não aceitação de tal serviço, e em protesto às ações da administração petista encaminhadas pelo NAE (ação prevista na LDB/96 e em portaria municipal específica), decidiram fazer uma leitura do texto viabilizando o transporte de forma inadequada. No item que se reportava ao critério de distância para o acesso ao atendimento do transporte, estabelecido como dois Km o percurso mínimo entre moradia do aluno e a escola, a ação da escola, que era de verificar quais alunos moravam mais distante, foi repassada para os condutores do transporte. Estes interpretaram o texto considerando a distância a partir dessa quilometragem e não das distâncias

22 UMES (União Municipal dos Estudantes Secundaristas), UBES (União Brasileira de Estudantes Secundaristas), UPES (União Paulista de Estudantes Secundaristas), UNE (União Nacional dos Estudantes), Força Ativa (Grupo de Jovens constituído na Cidade Tiradentes-SP, com atuação cultural e educativa na região, realizando palestras que traziam a pedagogia de Paulo Freire para a discussão com outros jovens). 
maiores até encerrar atendimento aos que estavam distantes da escola a apenas dois $\mathrm{km}$. Esse procedimento acarretou o não atendimento a quem morava a 4, $5 \mathrm{~km}$ da escola.

A situação foi denunciada pelas mães de crianças não atendidas ao setor de GD e a algumas mães participantes do CRECE. Com a constituição de uma comissão a partir do CRECE, as ações foram por ela acompanhadas e fiscalizadas. Essa atitude desencadeou reuniões com todos os diretores das escolas e, posteriormente, com os condutores do transporte que, não raras vezes foram vistos deixando as crianças que transportavam no meio do caminho, alegando não ter condições de circular por ruas consideradas por eles como inadequadas, com buracos, sem asfalto, distante da avenida principal. A identificação da ocorrência levou a equipe GD a organizar e atuar, periodicamente, com proposta de formação visando melhoria na qualidade do atendimento as crianças e definição de suas atribuições, pelos 90 condutores escolares do programa Vai e Volta (transporte escolar gratuito).

Em reunião realizada em (20/4/2004), o entrevistado ${ }^{23}$ A. (da equipe de GD), esclarece para a mãe N. que a matrícula no Vai e Volta não é definitiva, devendo ser renovada a cada ano. Esclarece que os pais têm problemas, mas que não é possível resolvê-los, uma vez que um dos critérios elaborados no colegiado é o atendimento que visa às crianças. $O$ transporte escolar das crianças, trouxe uma articulação de demandas da região, sempre presente na pauta das reuniões. 0 caso da mãe N. ilustra a situação. Na reunião do CRECE, ela solicita que seja feito o cascalhamento da Estrada Adutora do Rio Claro, Jardim Parque das Flores. Dessa forma, haveria a possibilidade de transportar (com o Vai e Volta) as crianças em dias de chuva.

O conselheiro D. ao fazer parte da discussão no CRECE, na condição de paraplégico, solicita que o "Atende" veículo, que transporta pessoas com deficiência para atendimento e tratamento médico, seja um transporte geral, levando o deficiente, também, para outros serviços, por exemplo, para agência bancária. D. era, frequentemente, visto se arrastando pelas ruas do entorno do CEU São Mateus para ir para a EJA, solicitou também uma cadeira de rodas.

Como atestam os registros de atas, nas reuniões do CRECE eram, também, evidenciados conflitos recorrentes nas reuniões de CE e em outras reuniões com as equipes escolares. Paro (2011) alerta que os conflitos surgidos no CE não são criados por ele; antes são manifestações de conflitos ocorridos em outros espaços da escola e que devem ser enfrentados e encaminhados coletivamente. Há registros como demanda no CRECE, sobre a necessidade de aproximação dos debates sobre GD do pessoal que compunha o quadro de apoio à ação educativa na escola (inspetores, agentes escolares, pessoal da cozinha, da limpeza). Em uma oficina realizada com um desses grupos, foi

${ }^{23}$ Identificados por letra para manter anonimato. 
reveladora a fala de uma agente escolar quando desenhou em uma cartolina um enorme revólver e relatar que era daquela forma que ela se sentia na relação com a direção escolar; com uma arma na sua cabeça todos os dias (AUTORA, ANO). O relato chocante ilustrava, de maneira contundente, a relação opressor e oprimido que persistia em várias escolas (FREIRE, 1979).

Com a necessidade da discussão de questões legais apontadas no CRECE, que envolviam os direitos e deveres dos profissionais da educação e, também, da comunidade, propôs-se junto ao CRECE oficinas, cujo tema voltava-se para o Regimento Escolar pós-LDB. Com a aprovação da proposta, surgiu a necessidade de preparar um material lúdico para estudar o Regimento escolar à luz do Regimento Comum das Escolas Municipais - RCEM/1992, dado seu avanço na proposta da democratização da escola.

Nova comissão de trabalho, oriunda do CRECE foi formada. Composta por professores, coordenadoras pedagógicas, pais que, ao lerem o Regimento Comum das Escolas Municipais24, destacaram os pontos de dificuldade de entendimento de termos, conceitos ou encaminhamentos truncados na prática. Elaboraram questões que, posteriormente, foram adaptadas constituindo um jogo, que recebeu o nome de Trilha Democrática. Esse material foi importante para desencadear as discussões sobre gestão democrática nas escolas e, também, nas creches da região que começavam a fazer parte do sistema educacional naquele momento, sendo o CRECE um espaço acolhedor de suas demandas. A publicação de materiais de divulgação e de formação que ressaltavam a importância da participação ativa na tomada das decisões da escola, na ocupação dos espaços democráticos de participação foi uma das estratégias adotadas pela parceria. Essas publicações foram construídas com a participação ativa do CRECE, com a colaboração de coordenadores pedagógicos, em alguns casos, diretores e professores e alunos não atuantes diretamente no CRECE.

No quadro de ações desenvolvidas em parceria com o CRECE, colocou-se a proposta de discutir temas para a publicação de caderninhos envolvendo a GD, nos horários de encontros coletivos na escola como: formação dos professores, CE, Grêmio Estudantil, protagonismo dos estudantes, participação, representação, entre outros. Os professores, por adesão, desenvolveriam os temas com as crianças e adolescentes e solicitariam que elas elaborassem materiais, cujo objetivo seria chamar a atenção do leitor, instigando-o a participar desses espaços democráticos. A comissão do CRECE e a equipe do NAE (Coordenadoria), ao receber os trabalhos das escolas, elaboraram critérios para análise do material produzido. Eles deveriam ter a possibilidade de pegar o máximo de contribuições para as

24 Utilizou-se o Regimento Comum das Escolas Municipais por entender ser este documento fruto de ampla discussão realizada na administração do PT de 1989 a 1992, traduzindo princípios claros e coerência conceitual para as nossas ações. 
publicações como: ideias, desenhos, frases, personagens, organização da proposta, fotos, entre outros.

A partir da junção das contribuições e com a apreciação do CRECE, o lançamento das publicações ocorreu em um grande evento, que ocupou um auditório do SESC Itaquera, com a participação de alunos e seus familiares, professores, diretores e coordenadores pedagógicos. Naquele momento, todas as contribuições foram lembradas. Todos aqueles que participaram diretamente do processo foram chamados ao palco e, por representação, falaram como foi vivenciar essa experiência, que culminou com as publicações de caderninhos em cada momento. Foram elas: "Toinzinho em: Que tal um bom Conselho?"; "Sugestão Democrática"; "Caderno do Grêmio $1^{\mathrm{a}}$ e $2^{\mathrm{a}}$ edição"; Jogo Trilha Democrática. A preocupação do governo local e do CRECE com a construção coletiva, com a aproximação entre comunidade, escola e instância regional do governo proporcionou momentos de formação política, de exercício da prática democrática, da constituição da relação de poder coletivo uns com os outros (FREIRE 1979; PARO, 2008).

Entre as demandas apresentadas no CRECE, surgem aquelas voltadas à democratização das relações na escola e em demais espaços públicos. $O$ debate era sobre ações pautadas pela exclusão dos alunos considerados "difíceis". Decorrente dessa discussão, foi realizado atendimento específico às escolas que solicitaram ações para a melhoria nas relações internas, entre os diferentes segmentos e deles com a comunidade externa.

Foram realizadas atividades integradoras organizadas em forma de oficinas contando com a participação de representantes do Centro de Defesa da Criança e do Adolescente - CEDECA, Conselho Municipal dos Direitos da Criança e do Adolescente - CMDCA, do Conselho Tutelar, da Secretaria de Assistência Social - SAS e do Subprefeito da região Sr. Franco Torresi, em oficina mediada por um convidado do Núcleo de Trabalhos Comunitários da Pontifícia Universidade Católica de São Paulo - NTC/PUC/SP, psicoterapeuta Sr. José Carlos Bimbatte. Esses momentos de exercício, na perspectiva da democratização das relações (PARO, 2008; 2011), foram importantes para refletir e debater questões que afligiam e angustiavam o grupo de educadores da escola, em relação às dificuldades de como lidar com crianças e adolescentes em situação de extrema vulnerabilidade.

Ampliando seu campo de atuação, o CRECE também esteve presente nas discussões e encaminhamentos voltados à elaboração e organização do encontro "Negra Cidade Leste", que ocorreu em duas escolas, apoiado pelo trabalho coletivo entre o NAE 9 (Bairro Itaquera, centro e distritos), NAE 13 (Bairro São Mateus centro e distritos) e NAE 10 (Bairro São Miguel centro e distritos). Essas ações, demandas das escolas e/ou da região, evidenciaram importante atuação política do CRECE territorialmente, consonante com pressupostos da cidade educadora, impulsionado regionalmente 
pelos debates nos polos ou na atuação das comissões executivas, com a possibilidade de direcionar aquelas não restritas às questões das escolas, diretamente, aos setores da Subprefeitura responsáveis pelas providências e encaminhamentos possíveis. Essas ações locais, em certa medida, foram ignoradas pela SME, escaparam ao acompanhamento, participação, colaboração e mesmo registro pelas instâncias superiores.

Diante das propostas democratizantes desenvolvidas, pautadas no princípio constitucional da GD e por autores emblemáticos que defendem a construção coletiva, a participação da comunidade na escola, a constituição de espaços democráticos de participação e formação na região ilustra o cenário de atuação do CRECE, cumprindo seu papel como conselho que atua, representando a vontade da sociedade (BORDIGNON, 2009). Diante de tantos desafios, o CRECE da região de São Mateus, rechaçando expressar a vontade exclusiva do governo, propondo-se a com ele elaborar e encaminhar propostas, atuou contribuindo com a elaboração de políticas públicas educacionais para a região.

\section{CONSIDERAÇÕES FINAIS}

Os registros, depoimentos, memórias sobre as ações em que o CRECE esteve envolvido na região de São Mateus, zona leste da capital paulista (2001 - 2004), evidenciam a preocupação com um tipo de atuação pautada pelo princípio constitucional da GD bem como pela perspectiva da cidade educadora. Como espaço democrático de participação, o CRECE desenvolveu ações propositivas, formativas, fiscalizadoras, de acompanhamento da política educacional no âmbito regional consonante com a cidade educadora. Acolheu e encaminhou demandas apresentadas pela população. Ademais, teve participação ativa na parceria firmada com a instância regional de educação, não atuando de forma a referendar suas propostas, mas construindo com ela possibilidades de ação em prol da coletividade.

A partir da constituição de comissões o CRECE ampliou sua possibilidade de inserção na região. Respeitando a autonomia da escola e, ao mesmo tempo, buscando ações comprometidas com práticas democráticas, preocupou-se com autonomia e garantia de direitos das crianças e adolescentes. Ainda, ousou, por vezes, de forma lúdica e educativa, desnaturalizar relações de poder de uns sobre outros, criando possibilidades de relação de poder com o outro proporcionando empoderamento das pessoas (PARO, 2008).

A construção coletiva pautada pela ênfase na participação ativa da população (BENEVIDES, 1994) nas instâncias de poder, na transparência, no exercício da escuta, revelou formas diferenciadas 
de divulgação das ações, inclusive por meio de publicações construídas a várias mãos num processo educativo em que todos tinham a aprender (FREIRE, 1993).

Nesse cenário, a parceria estabelecida entre a equipe do NAE/Coordenadoria e o CRECE revelou avanços e possibilidades. Um avanço foi o fortalecimento mútuo, distante das demandas e fiscalização da SME. A distância não necessariamente foi de cunho negativo, pois conferiu certa autonomia à equipe de GD e ao CRECE que, até metade do governo, não estiveram presos ao cumprimento de agendas ditadas de cima para baixo, voltadas ao atendimento e necessidades de um governo, também marcado por ações de visibilidade, centrando-se, prioritariamente, nas demandas apresentadas pela população.

Como possibilidade, ficou seu potencial educador e articulador regional na perspectiva da cidade educadora, a construção de proximidade entre as escolas, a articulação para a apresentação de suas demandas territorialmente. Ações como aquelas ocorridas em São Mateus, entre outras possíveis desenvolvidas pela cidade, marcam, de forma positiva e política de um bairro se constituindo como educador para e com a cidade educadora. Ressalta-se que após 2004, com a mudança de diretrizes do novo governo, o CRECE sai de cena na região, bem como em boa parte da cidade. É retomado como política educacional na região apenas em 2015, com sua institucionalização tornando-0 obrigatório para toda a cidade através da Lei Municipal $n^{0} 16.213$, regulamentada pelo Decreto $n^{0}$ 56.520 .

Verificou-se que são raros os registros acadêmicos com foco no CRECE, o que reforça a relevância de tomá-lo como objeto de estudo contemplando a divulgação de suas experiências até então colocadas num campo invisível, contribuindo com o registro de sua história na história da cidade que se lançou como cidade educadora.

\section{REFERÊNCIAS}

DOURADO, Luiz Fernandes. Políticas e gestão: novos marcos regulatórios da educação no Brasil. São Paulo: Xamã, 2009.

AIETA, Vânia Siciliano; ZUIN, Aparecida Luiza Alzira. Princípios Norteadores da Cidade Educadora. Revista de Direito da Cidade, Rio de Janeiro, vol.04, nº 02, p. 193-232. 2012

APPLE, Michel; BEANE, James A. (Org.). Escolas democráticas. 2. ed. São Paulo: Cortez, 2001.

ARELARO, L. R. G., and CABRAL, M. R. M. Paulo Freire: por uma teoria e práxis transformadora. In: BOTO, C., ed. Clássicos do pensamento pedagógico: olhares entrecruzados [online]. Uberlândia: 
EDUFU, 2019, pp. 267-292. História, Pensamento, Educação collection. Novas Investigações series, vol. 9.

BENEVIDES, Maria Vitória de Mesquita. Cidadania e democracia. Lua Nova: Revista de Cultura e Política, São Paulo, n. 33, p. 5-16, 1994.

BORDIGNON, Genuíno. Gestão da educação no município: sistema, conselhos e planos. São Paulo: Instituto Paulo Freire: Ed. L, 2009.

BORDIGNON, Genuíno; GRACINDO, Regina Vinhaes. Gestão da Educação: o município e a escola. In: FERREIRA, Naura Syria Carapeto; AGUIAR, Márcia Ângela da S. (Org.). Gestão da Educação: impasses, perspectivas e compromissos. São Paulo: Cortez, 2009. p. 147-176.

BOURDIEU, Pierre. Compreender. In: BOURDIEU, Pierre (Coord.). A miséria do mundo. 4. ed. Petrópolis: Vozes, 2001. p. 693-732.

CELLARD, André. A análise documental. In: POUPART, Jean et al. A pesquisa qualitativa: enfoques epistemológicos e metodológicos. Tradução: Ana Cristina Nasser. Petrópolis: Vozes, 2008. p. 295-316.

DI GIOVANNI, Geraldo; NOGUEIRA, Marco Aurélio (orgs). Dicionário de políticas públicas. 2.ed. São Paulo: Editora da Unesp/Fundap, 2015.

FREIRE, Paulo. Pedagogia do oprimido. 7. ed. São Paulo: Paz e Terra, 1979.

FREIRE, Paulo. A cidade na Educação. São Paulo: Cortez, 1991.

Política e educação. São Paulo: Cortez, 1993.

LUCK, Heloísa. Gestão educacional: uma questão paradigmática. Petrópolis: Vozes, 2006.

PARO, Vitor Henrique. Administração escolar: introdução crítica. 17. ed São Paulo: Cortez, 2012.

Crítica à estrutura da escola. São Paulo: Cortez: 2011.

Cortez, 2008.

Educação como exercício de poder: crítica ao senso comum em educação. São Paulo:

SANTOS, Ubiratan de Paula; BARRETTA, Daisy. Subprefeituras: descentralização e participação popular em São Paulo. São Paulo: Hucitec: PMSP, 2004.

SÃO PAULO. Decreto $n^{0}$ 56.520, de 16 de outubro de 2015. Regulamenta a Lei $n^{0} 16.213$, de 17 de junho de 2015, que dispõe sobre a criação e funcionamento do Conselho de Representantes dos Conselhos de Escola - Crece, bem como inclui o inciso XIV no artigo 118 da Lei n 14.660, de 26 de dezembro de 2007. São Paulo, 2015.

SILVA, Camilla Croso et al. Educação na capital paulista: um ensaio avaliativo da política municipal (2001-2002). São Paulo: Instituto Pólis; PUC-SP, 2004. (Observatório dos Direitos do Cidadão: acompanhamento e análise das políticas públicas da cidade de São Paulo, 20). 
SOUZA, Celina. Políticas públicas: questões temáticas e de pesquisa (Dossiê) Caderno CRH, Salvador, n. 39, p. 11-24, jul./dez. 2003.

Políticas Públicas: uma revisão da literatura. Sociologias, Porto Alegre, ano 8, n 16, jul/dez 2006, p. 20-45. 2006.

TATAGIBA, Luciana; TEIXEIRA, Ana Cláudia Chaves. Participação e democracia. Civitas, v. 6, n. 1, Porto Alegre, p. 223-240, jan./jun., 2006. 